\title{
Estimating total body water content in suckling and lactating llamas (Lama glama) by isotope dilution
}

\author{
Alexander Riek • Martina Gerken
}

Accepted: 11 March 2010 / Published online: 10 April 2010

(C) Springer Science+Business Media B.V. 2010

\begin{abstract}
Total body water (TBW) in 17 suckling and six lactating llamas was estimated from isotope dilution at three different post natum and lactation stages using both ${ }^{18} \mathrm{O}$ and deuterium oxide $\left(\mathrm{D}_{2} \mathrm{O}\right)$. In total, 69 TBW measurements were undertaken. While TBW in lactating dams, expressed in kilogram, remained stable during the three measurement periods $(91.8 \pm 15.0 \mathrm{~kg}$ ), the body water fraction (TBW expressed in percent of body mass) increased slightly $(P=$ 0.042 ) from $62.9 \%$ to $65.8 \%$. In contrast, TBW (kilogram) in suckling llamas increased significantly $(P<0.001)$ with age and decreased slightly when expressed as a percentage of body mass $(P=0.016)$. Relating TBW to body mass across all animals yielded a highly significant regression equation (TBW in kilogram $=2.633+0.623$ body mass in kilogram, $P<0.001, n=69$ ) explaining $99.5 \%$ of the variation. The water fraction instead decreased in a curve linear fashion with increasing body mass (TBW in percent of body mass $=88.23$ body mass in kilogram ${ }^{-0.064}, P<$ $0.001, R^{2}=0.460$ ). The present results on TBW can serve as reference values for suckling and lactating llamas, e.g., for the evaluation of fluid losses during disease. Additionally, the established regression equations can be used to predict TBW from body mass, providing that the body masses fall inside the range of masses used to derive the equations.
\end{abstract}

\footnotetext{
A. Riek $\cdot$ M. Gerken

Department of Animal Sciences, University of Goettingen,

Albrecht-Thaer-Weg 3,

37075 Goettingen, Germany

Present Address:

A. Riek ( $\square)$

Centre for Behavioural and Physiological Ecology, Zoology,

University of New England,

Armidale, New South Wales 2351, Australia

e-mail: ariek2@une.edu.au
}

Keywords Llama $\cdot$ Lactation · Isotope dilution · Deuterium . Total body water

\section{Introduction}

Isotope dilution methods have been used for many years in animals and humans to measure body composition (Arnold et al. 1985; Andrew et al. 1995; Speakman et al. 2001), milk intake (Oftedal 1981; Holleman et al. 1982; Butte et al. 1988; Ahlstrom and Wamberg 2000; Riek et al. 2007), energy metabolism (for review, see Nagy et al. 1999; Speakman 2000), water turnover, and total body water (TBW; Culebras et al. 1977; Sheng and Huggins 1979; Degen et al. 1991; Andrews et al. 1997; Bowen and Iverson 1998). The direct measurement of TBW in animals and humans involves the application of specific markers that distribute evenly in body water (Holleman et al. 1982). The most common markers used to measure TBW are stable isotopes such as ${ }^{18} \mathrm{O}$ or deuterium oxide $\left(\mathrm{D}_{2} \mathrm{O}\right)$. A detailed description of the method has been published previously (Speakman et al. 2001).

TBW has been measured extensively in many domesticated species including pigs (Houseman et al. 1973), cattle (Arnold et al. 1985), sheep (Dove 1988), horses (Andrews et al. 1997), and dogs (Scantlebury et al. 2000). However, only a few values are available for domesticated South American camelids (Rübsamen and Engelhardt 1975, Marcilese et al. 1994) and none for llamas at different lactation or post natum stages. Considering the increasing numbers of llamas kept for wool or as pet and companion animals outside South America, especially in Europe, Australia, and North America, knowledge of body composition and thus TBW are needed, e.g., to develop fluid therapy plans in case of dehydration. 
To the authors' knowledge, so far, there are no established TBW values for suckling and lactating llamas available in the literature. Therefore, the purpose of the present study was to establish these values and additionally derive prediction equations from which TBW can be estimated. These established values could serve as reference values for suckling and lactating llamas in the evaluation of fluid losses, e.g., during disease.

\section{Materials and methods}

A total of 17 suckling (crias) and six lactating llamas (dams) were used to measure the TBW content at three different ages and lactation stages at the times 3-4, 10-11, and 18-19 weeks post natum and post partum, respectively. In total, 69 TBW measurements were undertaken in the years 2006-2007. This study was part of a larger project investigating various aspects of growth, water metabolism, and lactation in llamas.

\section{Animals and management}

Animals originated from a herd of the Experimental Station Relliehausen of Goettingen University and a private German breeder. All animals were bred in Europe. Animals were transferred 3 months prior to parturition for acclimatization and were kept at the Department of Animal Sciences, University of Goettingen, Germany, under controlled stable conditions. Each room measured $5.8 \times 3.2 \mathrm{~m}$, and animals had permanent access to an outdoor pen. In the stable, light schedule was kept constant (14 h light to $10 \mathrm{~h}$ dark). Llama dams received twice daily $0.5 \mathrm{~kg}$ of a commercial mixed grain and molasses feed containing $16.0 \%$ crude protein $(\mathrm{CP}), 12.0 \%$ crude fiber, $3.0 \%$ crude fat, $1.2 \%$ calcium, $0.5 \%$ phosphorus, $0.3 \%$ sodium, $8.5 \%$ ash, and $10.2 \mathrm{MJ} / \mathrm{kg}$ of metabolizable energy (HG $58 \mathrm{~S}$, Raiffeisen-AGRAVIS AG, Rosdorf, Germany). Hay from ryegrass-dominated grassland (dry matter $(\mathrm{DM}), 860 \mathrm{~g} / \mathrm{kg}$ fresh matter; crude ash, $94 \mathrm{~g} / \mathrm{kg} \mathrm{DM}$; CP, $131 \mathrm{~g} / \mathrm{kg} \mathrm{DM}$; ether extract, $26 \mathrm{~g} / \mathrm{kg} \mathrm{DM}$; crude fiber, $283 \mathrm{~g} / \mathrm{kg} \mathrm{DM}$; nitrogen free extractives, $466 \mathrm{~g} / \mathrm{kg} \mathrm{DM}$ ), water, and mineral feed (HG MIN 13, Raiffeisen-AGRAVIS AG, Minden Westf., Germany) were available ad libitum.

Isotope application and isotope measurements

Measurements for all animals were conducted at three different measurement periods, namely, weeks 3 to 4,10 to 11 , and 18 to 19 post natum and post partum, respectively.

Two hours before isotope administration, crias were separated from their dams. Immediately before the isotope administration, a background blood sample was taken from both the dam and the cria in blood tubes containing citrate to prevent coagulation.

Dams $(n=6)$ and crias $(n=11)$ received an intramuscular dose of $\mathrm{D}_{2} \mathrm{O}$ of $99.90 \%$ purity (Euriso-top $\mathrm{GmbH}$, Saarbruecken, Germany). The individual amount administered was determined by the mass of the animal which was measured with a scale to the nearest of $0.5 \mathrm{~kg}$ for the dam (Tru-Test model SR2000 MR, Tru-Test Limited, Auckland, New Zealand) and 0.005 for the cria (Sartorius model CW3P1-150IG-I, Sartorius AG, Goettingen, Germany) prior to the isotope application. The mean $\mathrm{D}_{2} \mathrm{O}$ amounts administered to the dams $(n=6)$ per kilogram body mass were $0.198 \pm 0.004,0 \cdot 201 \pm 0.008$, and $0.200 \pm 0.007 \mathrm{~g}$ (mean $\pm \mathrm{SD}$ ), and to the crias $(n=11)$, they were $0.310 \pm$ $0.015,0.206 \pm 0.015$, and $0.148 \pm 0.022 \mathrm{~g}$ at weeks $3-4,10$ 11 , and $18-19$ post partum, respectively.

In 2007, TBW in crias $(n=6)$ was estimated by $\mathrm{H}_{2}{ }^{18} \mathrm{O}$. Crias were given an intramuscular dose of $\mathrm{H}_{2}{ }^{18} \mathrm{O}$ with an ${ }^{18} \mathrm{O}$ content of $10.10 \%$ (Euriso-top $\mathrm{GmbH}$, Saarbruecken, Germany). The mean amounts administered were $0.138 \pm$ $0.010,0.138 \pm 0.003$, and $0.094 \pm 0.001 \mathrm{~g}$.

Volumes were injected i.m. at multiple sites of the body. Animals did not exhibit any unusual signs of discomfort. The actual dose given was gravimetrically measured by weighing the syringes before and after the administration to the nearest of $0.001 \mathrm{~g}$. Blood samples of $6 \mathrm{ml}$ were then taken from the jugular vein for each measurement period for 7 days.

Blood samples were centrifuged, and an approximate $3 \mathrm{ml}$ of plasma were pipetted into glass vials and then frozen at $-20^{\circ} \mathrm{C}$ until the determination of the ${ }^{2} \mathrm{H}$ and ${ }^{18} \mathrm{O}$ concentration.

Earlier work showed that tracer concentrations in plasma samples are the same as in vacuum-sublimated water samples (Riek et al. 2007). Therefore, plasma samples were used to measure ${ }^{2} \mathrm{H}$ and ${ }^{18} \mathrm{O}$ concentrations.

Analyses were carried out at the Competence Center of Stable Isotopes (KOSI, Goettingen University, Goettingen, Germany). Isotope ratios of ${ }^{2} \mathrm{H}$ and ${ }^{18} \mathrm{O}$ were measured using an on-line high temperature reduction technique in a helium carrier gas described previously (Gehre et al. 2004) and expressed relative to the Vienna standard mean ocean water (VSMOW), which is the international reference standard for $\mathrm{D}_{2} \mathrm{O}$ and ${ }^{18} \mathrm{O}$. Individual samples were measured in triplicate and the averages calculated.

\section{Calculations}

Isotope equilibration concentrations were computed for each cria and dam by the extrapolation to zero time by the equation

$C_{t}=C_{0} \times e^{-k \times t}$ 
where $C_{0}$ is the equilibration concentration (intercept), $k$ is the fractional water turnover (slope), and $t$ is the time elapsed since tracer administration (Holleman et al. 1982).

Isotope equilibration and pre-dose baseline concentrations were then used to calculate the dilution spaces for $\mathrm{D}_{2} \mathrm{O}\left(V_{\mathrm{D}}\right)$ or ${ }^{18} \mathrm{O}\left(V_{\mathrm{O}}\right)$ by using the following formula (Schoeller et al. 1986):

$$
\begin{aligned}
V_{\mathrm{D}} \text { or } V_{\mathrm{O}}= & {\left[D \times \mathrm{APE}_{\text {dose }} \times 18.02 \mathrm{~g} / \mathrm{mole}\right] } \\
& /\left[\mathrm{MW}_{\text {dose }} \times 100 \times\left(C_{0}-C_{\mathrm{b}}\right) \times R\right]
\end{aligned}
$$

where $D=$ dose given in grams, $\mathrm{APE}_{\text {dose }}=$ atomic enrichment of the dose in percent $\left(99.90 \%\right.$ for $\mathrm{D}_{2} \mathrm{O}$ and $10.10 \%$ for $\mathrm{H}_{2}{ }^{18} \mathrm{O}$ ), $\mathrm{MW}_{\text {dose }}=$ molecular weight of the dose, $C_{0}=$ isotope equilibration concentration expressed as delta $D$ vs. VSMOW, $C_{\mathrm{b}}=$ pre-dose baseline concentration, and $R=$ ratio of $\mathrm{D}_{2} \mathrm{O}$ or $\mathrm{H}_{2}{ }^{18} \mathrm{O}$ to hydrogen or oxygen, respectively, in VSMOW (i.e., $1.5574 \times 10^{-4}$ for hydrogen and $2.0052 \times 10^{-3}$ for oxygen).

$V_{\mathrm{D}}$ was divided by 1.04 and $V_{\mathrm{O}}$ by 1.01 to calculate the TBW content as compiled data suggest that the dilution spaces for $\mathrm{D}_{2} \mathrm{O}$ and ${ }^{18} \mathrm{O}$ are overestimated by approximately $4 \%$ and $1 \%$, respectively (Schoeller 1983).

\section{Statistical analysis}

Statistical analyses were performed with the software package Statistical Analysis Systems version 9.01 (SAS, 2001). For extrapolating the regression of $C_{t}$ on time by Eq. 1, the nonlinear regression procedure (PROC NLIN) in SAS was used. After correction of the $V_{\mathrm{D}}$ and $V_{\mathrm{O}}$ spaces, isotope $\left(\mathrm{D}_{2} \mathrm{O}\right.$ or ${ }^{18} \mathrm{O}$ ) exerted no significant influence on body mass and calculated TBW in crias $(P>0.05)$ as well as sex. Accordingly, a two-way analysis of variance was performed including only the effects of age (crias)/lactation stage (dams; i.e., post natum and post partum) and animal, using the general linear model procedure (PROC GLM), with animal as random and age/lactation stage as fixed effect: $Y_{i j k}=\mu+A_{i}+T_{j}+e_{i j k}$; where $Y_{i j k}=$ observation value, $\mu=$ overall mean, $A_{i}=$ fixed effect of the $i$ th age/lactation stage $(i, 1=3-4,2=10-11,3=$ 18-19 weeks post natum/partum), $T_{j}=$ random effect of the animal, and $e_{i j k}=$ random error. An integrated multiple range test (Student-Newman-Keuls) was used to detect differences between means with a 5\% significance level.

\section{Results}

Body mass and TBW content for the three measurement periods are presented in Table 1. Body mass and TBW in kilogram in crias increased with age and were significantly affected by the individual animal $(P<0.001)$. However, when TBW was expressed as a percentage of body mass (water fraction), the effect of the animal was eliminated, and TBW decreased only slightly with age $(P=0.016)$.

In lactating dams, body mass was significantly $(P<0.001)$ affected by the individual animal and decreased slightly with lactation stage $(P=0.047)$. TBW instead remained fairly stable during the three measurement periods and averaged $91.8 \mathrm{~kg}$. The body water fraction increased slightly $(P=0.042)$ from $62.9 \%$ to $65.8 \%$ with lactation stage.

Calculating a conventional linear regression between TBW in kilogram and body mass, using all available data points for crias and dams $(n=69)$, produced a highly significant regression line (TBW in kilogram $=2.633+0.623$ body mass in kilogram, $\left.F_{1,67}=12,833, P<0.001\right)$ explaining nearly all the variation $(99.5 \%)$ in TBW (Fig. 1). The water fraction however was less well explained by body mass and decreased with increasing body mass in a curve linear fashion (TBW in percent of body mass $=88.23$ body mass in kilogram $^{-0.064}, F_{1,67}=11,368, P<0.001, R^{2}=0.46$ ).

\begin{tabular}{|c|c|c|c|c|c|c|}
\hline \multirow[t]{3}{*}{ Time post natum/partum (weeks) } & \multicolumn{3}{|c|}{ Suckling crias $(n=17)$} & \multicolumn{3}{|c|}{ Lactating dams $(n=6)$} \\
\hline & \multirow{2}{*}{$\begin{array}{l}\text { Body mass } \\
(\mathrm{kg})\end{array}$} & \multicolumn{2}{|c|}{ Total body water } & \multirow{2}{*}{$\begin{array}{l}\text { Body mass } \\
(\mathrm{kg})\end{array}$} & \multicolumn{2}{|c|}{ Total body water } \\
\hline & & $(\mathrm{kg})$ & (\% of mass) & & $(\mathrm{kg})$ & (\% of mass) \\
\hline 3 & $18.63 \pm 1.00 \mathrm{a}$ & $13.76 \pm 0.73 \mathrm{a}$ & $74.03 \pm 1.21 \mathrm{a}$ & $148.7 \pm 11.5 \mathrm{a}$ & $92.9 \pm 5.6 \mathrm{a}$ & $62.89 \pm 1.21 \mathrm{a}$ \\
\hline 10 & $32.39 \pm 1.94 b$ & $22.24 \pm 1.28 b$ & $68.98 \pm 0.99 b$ & $141.3 \pm 11.4 b$ & $90.8 \pm 7.1 \mathrm{a}$ & $64.32 \pm 0.58 b$ \\
\hline 18 & $47.96 \pm 2.75 \mathrm{c}$ & $33.44 \pm 1.81 \mathrm{c}$ & $70.03 \pm 0.87 b$ & $139.3 \pm 11.2 b$ & $91.7 \pm 6.4 \mathrm{a}$ & $65.81 \pm 0.73 b$ \\
\hline \multicolumn{7}{|l|}{ Two-way analysis of variance } \\
\hline Animal effect & $P<0.001$ & $P<0.001$ & $P=0.727$ & $P<0.001$ & $P<0.001$ & $P=0.070$ \\
\hline Age effect & $P<0.001$ & $P<0.001$ & $P=0.016$ & $P=0.047$ & $P=0.693$ & $P=0.042$ \\
\hline
\end{tabular}

Table 1 Comparison of body mass and total body water (TBW) for suckling and lactating llamas (Lama glama; numbers are means \pm SE)

Mean values within a column with unlike letters $(\mathrm{a}, \mathrm{b}$, and $\mathrm{c})$ were significantly different $(P<0.05)$ based on Student-Newman-Keuls multiple range test for multiple comparisons 
Fig. 1 Relationship between body mass (kilogram) and total body water (TBW) expressed in kilogram $(\mathrm{TBW}$ in kilogram $=$ $2.633+0.623$ body mass in kilogram, $P<0.001, R^{2}=0.995$; crias, closed circles; dams, closed triangles) and in percent of body mass (TBW in percent of body mass $=88.23$ body mass in kilogram ${ }^{-0.064}$, $P<0.001, R^{2}=0.460$; crias, open circles; dams, open triangles) in suckling and lactating llamas

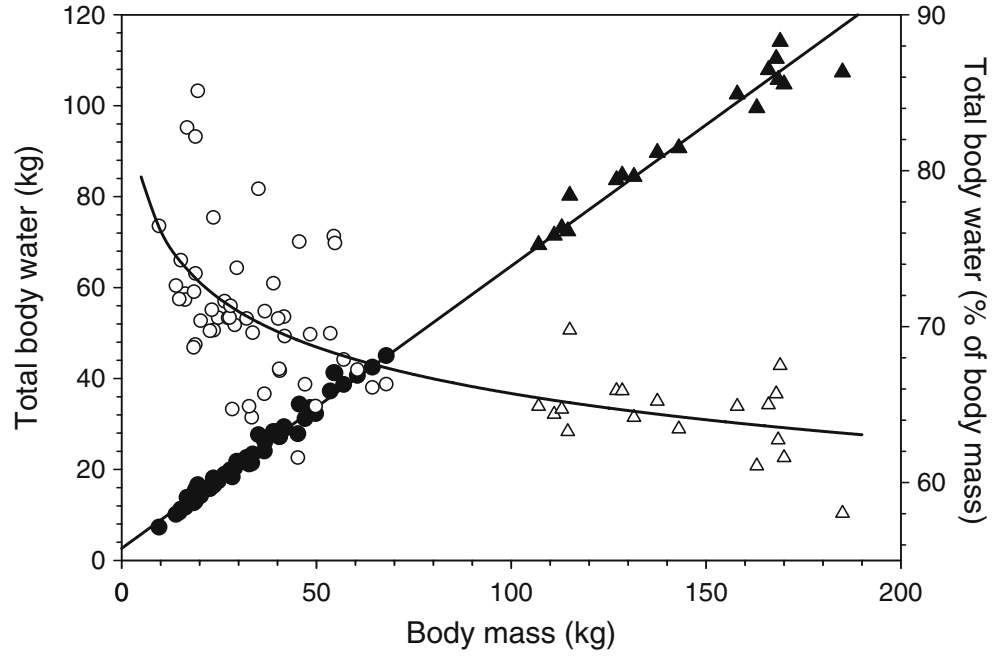

\section{Discussion}

The present results suggest that the TBW content in suckling crias increases from around $13 \mathrm{~kg}$ in weeks 3-4 post natum to around $34 \mathrm{~kg}$ in weeks $18-19$ post natum. While the TBW increased with age in crias, the water fraction decreased with increasing body mass (Fig. 1) and hence with increasing age. This observation is in accordance with results from previous studies on lambs (Dove 1988) and kids (Makinde 1993). It is suggested that body water content decreases relative to body mass with age primarily due to fat accumulation (Oftedal and Iverson 1989). In a previous study, Marcilese et al. (1994) reported a value of $71 \%$ body water in a single 14-day-old cria using isotope labeling. This is very close to the values found for the 17 crias of a similar age (3-4 weeks, Table 1) in the present study.

The body water fraction in lactating llamas was for all three lactation stages in the range of reported data on adult non-lactating llamas (Rübsamen and Engelhardt 1975), indicating that the body water fraction of lactating llamas ranges between $63 \%$ and $66 \%$ (Table 1). TBW in dams remained stable over the measurement periods, while the body water fraction slightly increased and body mass slightly decreased. Hence, the slight increase in the body water fraction is due to the decrease in body mass and not to a changing TBW. This should be kept in mind when treating lactating dams for fluid losses during disease, e.g., after shock and hypovolemia, because as Bedenice (2009) recently noticed, overaggressive fluid resuscitation is just as detrimental as under resuscitation.

Measured TBW values of suckling and lactating llamas over the three measurement periods produced a highly significant regression equation (TBW in kilogram $=2.633+$ 0.623 body mass in kilogram, Fig. 1) that explained $99.5 \%$ of the variation in TBW. The mean deviation of the prediction of TBW from that equation to the actual data was $4.85 \pm 4.04 \%$ (mean $\pm \mathrm{SD}$ ) making this equation a useful tool to predict TBW from body mass at least in suckling and lactating llamas. Similar prediction equations have been developed for humans (Chumlea et al. 2001) and dairy cattle (Andrew et al. 1995).

TBW volume was measured by the dilution technique using both $\mathrm{D}_{2} \mathrm{O}$ and ${ }^{18} \mathrm{O}$ labeling. A large body of literature exists describing the potential errors by using this method (Nagy 1980; Schoeller 1983; Speakman et al. 2001). One of the assumptions is that the isotope mixes completely and exclusively with the body water pool and is not incorporated in body tissue, which is generally the case (Oftedal and Iverson 1989). However, a small amount of the isotope might be lost to other body components such as rapidly exchangeable hydrogen atoms in organic molecules (e.g., proteins) resulting in a possible overestimation of TBW. Theoretically, this could amount up to $4 \%$ of the dilution space (Culebras et al. 1977; Schoeller 1983). In the present study, dilution spaces were corrected for these possible overestimations by established values (see "Materials and methods" for details). These estimates seem fairly accurate as no significant $(P>0.05)$ differences were detected for the respective measurement period between the water fraction of $\mathrm{D}_{2} \mathrm{O}$ and ${ }^{18} \mathrm{O}$ labeled animals after correction. Therefore, the isotope dilution technique seems to be the most accurate and noninvasive method to date to measure TBW in living animals and humans. Furthermore, comparative carcass analysis, measuring TBW directly in many species, was in good agreement with the estimation by the dilution procedure (Pinson 1952; Panaretto 1968; Houseman et al. 1973; Sheng and Huggins 1979; Odwongo et al. 1984; Schoeller et al. 1986; Bowen and Iverson 1998).

The present results are the first reporting TBW data for suckling and lactating llamas at different post natum and post partum stages. As so far there are no established TBW 
values for suckling and lactating llamas available in the literature, we recommend the present TBW data as limited reference data for healthy llamas and the use of the prediction equations to estimate TBW from body mass. However, this data can only be tentative until more data for a wider range of body mass become available.

Acknowledgements The authors wish to acknowledge the financial support from the European Union (DECAMA project, contract No. ICA4-CT-2002-10014). M. Gauly is specially thanked for the veterinary advice and Dr. E. Moors for taking the blood samples. We wish to thank J. Langel for organizing the isotope analyses and the Messing and Kraft families for their support by lending animals. The technical assistance of A. Oppermann and K. Salzmann of the Experimental Station Relliehausen and J. Dörl and the technical staff of the Department of Animal Science of the University of Goettingen is highly appreciated.

\section{References}

Ahlstrom, O., Wamberg, S., 2000. Milk intake in blue fox (Alopex lagopus) and silver fox (Vulpes vulpes) cubs in the early suckling period, Comparative Biochemistry and Physiology A, 127, 225-236

Andrew, S. M., Erdman, R. A., Waldo, D. R., 1995. Prediction of bodycomposition of dairy cows at 3 physiological stages from deuteriumoxide and urea dilution, Journal of Dairy Science, 78, 1083-1095

Andrews, F. M., Nadeau, J. A., Saabye, L., Saxton, A. M., 1997. Measurement of total body water content in horses, using deuterium oxide dilution, American Journal of Veterinary Research, 58, 1060-1064

Arnold, R. N., Hentges, E. J., Trenkle, A., 1985. Evaluation of the use of deuterium oxide dilution techniques for determination of body composition of beef steers, Journal of Animal Science, 60 , $1188-1200$

Bedenice, D., 2009. Approach to the critical ill camelid, The Veterinary Clinics of North America - Food and Animal Practice 25, 407-421

Bowen, W. D., Iverson, S. J., 1998. Estimation of total body water in pinnipeds using hydrogen-isotope dilution, Physiological Zoology 71, 329-332

Butte, N. F., Wong, W. W., Patterson, B. W., Garza, C., Klein, P. D., 1988. Human-milk intake measured by administration of deuterium oxide to the mother: a comparison with the test-weighing technique, American Journal of Clinical Nutrition 47, 815-821

Chumlea, W. C., Guo, S. S., Zeller, C. M., Reo, N. V., Baumgartner, R. N., Garry, P. J., Wang, J., Pierson, R. N., Heymsfield, S. B., Siervogel, R. M., 2001. Total body water reference values and prediction equations for adults, Kidney International 59, 2250-2258

Culebras, J. M., Fitzpatrick, G. F. Brennan, M. F., 1977. Total body water and the exchangeable hydrogen. II. A review of comparative data from animals based on isotope dilution and desiccation, with a report of new data from the rat, American Journal of Physiology 232, R60-R65

Degen, A. A., Kam, M., Rosenstrauch, A., Plavnik, I., 1991. Growth rate, total body water volume, dry matter intake and water consumption of domesticated ostriches (Struthio camelus), Animal Production 52, 225-232

Dove, H., 1988. Estimation of the intake of milk by lambs, from the turnover of deuterium- or tritium-labelled water, British Journal of Nutrition 60, 375-387

Gehre, M., Geilmann, H., Richter, J., Werner, R. A., Brand, W. A., 2004. Continuous flow ${ }^{2} \mathrm{H} /{ }^{1} \mathrm{H}$ and ${ }^{18} \mathrm{O} /{ }^{16} \mathrm{O}$ analysis of water samples with dual inlet precision, Rapid Communications in Mass Spectrometry 18, 2650-2660
Holleman, D. F., White, R. G., Luick, J. R., 1982. Application of the isotopic water method for measuring total body water, body composition and body water turnover. In: International Atomic Energy Agency (ed), Use of tritiated water in studies of production and adaptation in ruminants. (International Atomic Energy Agency, Nairobi, Kenya), 9-32

Houseman, R. A., McDonald, I., Pennie, K., 1973. The measurement of total body water in living pigs by deuterium oxide dilution and its relation to body composition, British Journal of Nutrition 30, 149-156

Makinde, M. O., 1993. Isotopic water dilution technique in body fluid measurement in some domestic animal species. Zentralblatt fur Veterinaermedizin A 40, 482-586

Marcilese, N. A., Ghezzi, M. D., Aba, M. A., Alzola, R. A., Solana, H., Valsecchi, R. M., 1994. Physiological studies in the South American camelid llama (Lama guanicoe f. d. glama). I. Body water spaces and water turnover, Acta Physiologica Pharmacologica et Therapeutica Latinoamericana 44, 36-42

Nagy, K. A., 1980. CO2 production in animals: Analysis of potential errors in the doubly labeled water method. American Journal of Physiology 7, 466-473

Nagy, K. A., Girard, I. A., Brown, T. K., 1999. Energetics of freeranging mammals, reptiles, and birds, Annual Review of Nutrition 19, $247-277$

Odwongo, W. O., Conrad, H. R., Staubus, A. E., 1984. The use of deuterium oxide for the prediction of body composition in live dairy cattle, Journal of Nutrition 114, 2127-2137

Oftedal, O. T., 1981. Milk, protein and energy intakes of suckling mammalian young: a comparative study, $(\mathrm{PhD}$ thesis, Cornell University)

Oftedal, O. T., Iverson, S. J., 1989. Hydrogen isotope methodology for measurement of milk intake and energetics of growth in suckling young. In: A. C. Huntley, D. P. Costa, G. A. J. Worthy and M. A. Castellini (eds), Approaches to marine mammal energetics. Society of Marine Mammalogy (Allen Press), 67-96

Panaretto, B. A., 1968. Some metabolic effects of cold stress on undernourished non-pregnant ewes, Australian Journal of Agricultural Research 19, 273-278

Pinson, E. A., 1952. Water exchanges and barriers as studied by the use of hydrogen isotopes, Physiological Reviews 32, 123134

Riek, A., Gerken, M., Moors, E., 2007. Measurement of milk intake in suckling llamas (Lama glama) using deuterium oxide dilution, Journal of Dairy Science 90, 867-875

Rübsamen, K., Engelhardt, W. V. 1975. Water metabolism in the llama, Comparative Biochemistry and Physiology A 52, 595-598

Scantlebury, M., Hynds, W., Booles, D., Speakman, J. R., 2000. Isotope recycling in lactating dogs (Canis familiaris), American Journal of Physiology 278, R669-R676

Schoeller, D. A., 1983. Energy-expenditure from doubly labeled water - some fundamental considerations in humans, American Journal of Clinical Nutrition 38, 999-1005

Schoeller, D. A., Ravussin, E., Schutz, Y., Acheson, K. J., Baertschi, P., Jequier, E., 1986. Energy-Expenditure by doubly labeled water - validation in humans and proposed calculation, American Journal of Physiology 250, R823-R830

Sheng, H. P., Huggins, R. A., 1979. A review of body composition studies with emphasis on total body water and fat, American Journal of Clinical Nutrition 32, 630-647

Speakman, J. R., 2000. The cost of living: Field metabolic rates of small mammals, Ecological Research 30, 177-297

Speakman, J. R., Visser, G. H., Ward, S., Krol, E., 2001. The isotope dilution method for the evaluation of body composition. In: J. R. Speakman (ed), Body composition analysis of animals - A handbook of non-destructive methods. (Cambridge University Press, Cambridge), 56-98 